\title{
Another tool towards invasion? Polyp 'bail-out" in Tubastraea coccinea
}
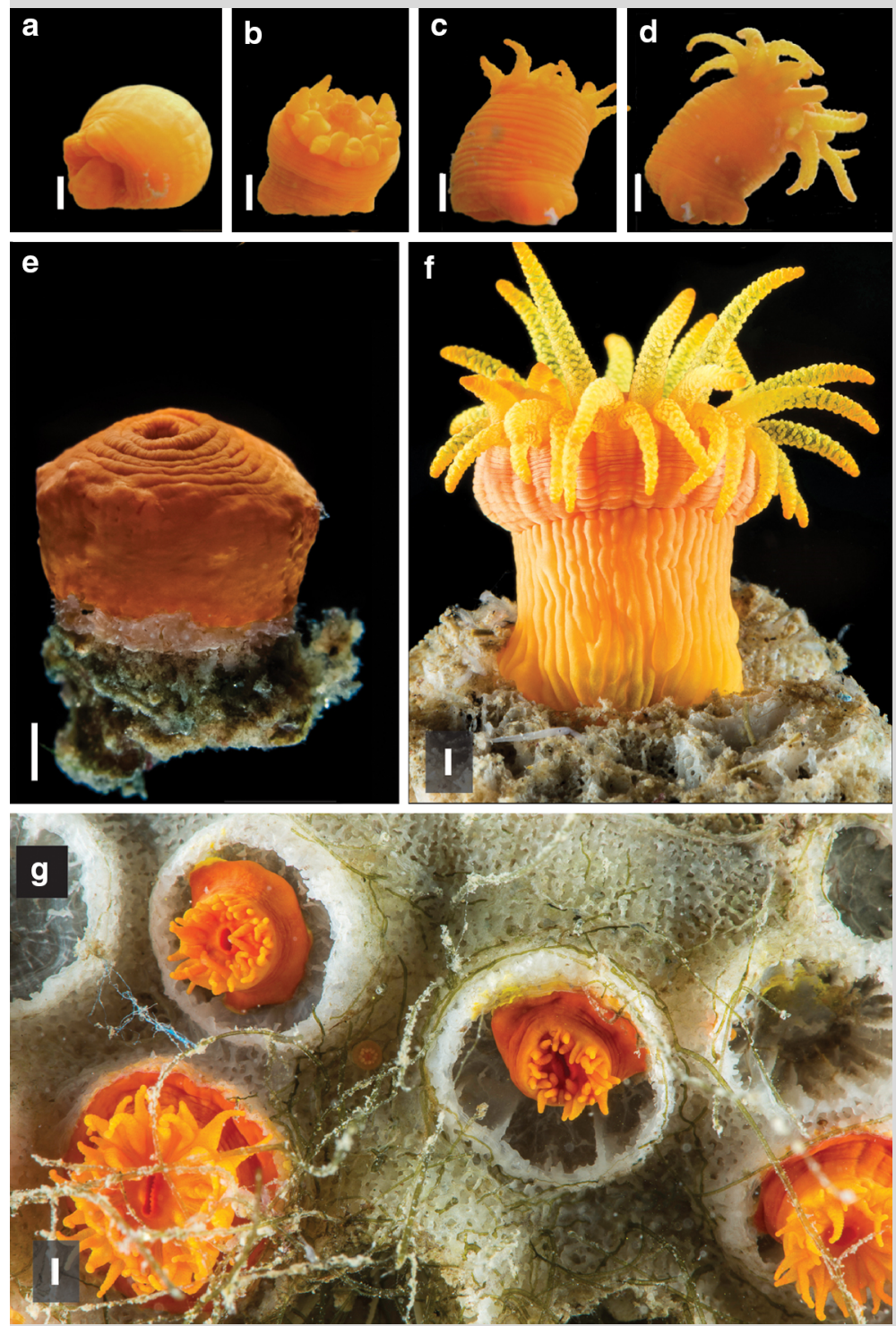

Fig. 1 Tubastraea coccinea "bail-out" polyp: a-d series of images showing the recently detached "bail-out" polyp during feeding [note the absence of a skeleton in (a)]; e retracted polyp after 6 months in the aquarium, with advanced skeletal development; $\mathbf{f}$ settled polyp after 7 months; g stressed colony showing polyps ready to detach from the skeleton. Scale bars indicate $1.0 \mathrm{~mm}$

K. C. C. Capel · A. E. Migotto · M. V. Kitahara

Centro de Biologia Marinha, Universidade de São Paulo, São Sebastião, Brazil

\section{K. C. C. Capel $(\bowtie) \cdot$ C. Zilberberg}

Instituto de Biologia, Universidade Federal do Rio de Janeiro, Rio de Janeiro, Brazil e-mail: katiacapel7@gmail.com

\section{V. Kitahara}

Departamento de Ciências do Mar, Universidade Federal de São Paulo, Santos, Brazil

Received: 20 May 2014/Accepted: 20 August 2014/Published online: 31 August 2014

(C) Springer-Verlag Berlin Heidelberg 2014
Known as a highly competitive invasive species that is spreading fast throughout the Atlantic Ocean, Tubastraea coccinea was first reported in Brazilian waters in the 1980s (Castro and Pires 2001). Since then, its occurrence has been reported across $3,000 \mathrm{~km}$ of the Brazilian coast, posing a major threat, particularly to sessile invertebrates. Among other characteristics, fast growth rate, early reproductive age, and year-round release of long-lived larvae are regarded as the main reasons for its success in colonizing new habitats (Glynn et al. 2008). After being collected at the São Sebastião channel $\left(23^{\circ} 48^{\prime} 55^{\prime \prime} \mathrm{S}\right.$,

$45^{\circ} 24^{\prime} 01^{\prime \prime} \mathrm{W}$ ), Brazil, several colonies of $T$. coccinea were kept in an open-water system aquarium and plankton-fed every other day. Approximately $30 \mathrm{~d}$ after collection, one single polyp around $20 \mathrm{~mm}$ in length (when fully extended) was found separated from the "mother" colony (Fig. 1a-d). To check whether this phenomenon was related to polyp "bail-out" (i.e., detachment of a single, non-skeletonized adult polyp from the colony; Goreau and Goreau 1959) the single polyp was radiographed using conventional X-ray film, which confirmed the absence of a calcareous structure. After 7 months, the polyp was still alive, having secreted a new skeleton and attached to the substrate (Fig. 1e, f). Another five polyp bail-outs occurred from a stressed colony. In this case, it was possible to observe the tissue receding from the coenosteum before the detachment of polyps (Fig. 1g). Two of those polyps died in 1 week; however, the other three remained alive after $9 \mathrm{~d}$. This observation demonstrates that under stressful conditions the polyps of $T$. coccinea are able to bail-out. In addition to its efficient reproductive strategies, polyp detachment may act as another propagation mechanism over long distances and, consequently, increases concerns about its invasive potential.

Acknowledgments We thank São Paulo Research Foundation-FAPESP (Grant \#2012/21583-1) for financial support. This is a contribution of the NP-BioMar, USP.

References

Castro CB, Pires DO (2001) Brazilian coral reefs: what we already know and what is still missing. Bull Mar Sci 69:357-371

Glynn PW, Colley SB, Mate JL, Cortés J, Guzman HM, Bailey RL, Feingold JS, Enochs IC (2008) Reproductive ecology of the azooxanthellate coral Tubastraea coccinea in the Equatorial Eastern Pacific: Part V. Dendrophylliidae. Mar Biol 153:529-544

Goreau TH, Goreau NI (1959) The physiology of skeleton formation in corals. II. Calcium deposition by hermatypic corals under various conditions in the reef. Biol Bull 117:239-250
Coral Reefs (2014) 33:1165 DOI $10.1007 / \mathrm{s} 00338-014-1200-\mathrm{z}$ 